International Business and Global Economy 2018, no. 37, pp. 533-543

Biznes międzynarodowy w gospodarce globalnej 2018, nr 37, s. 533-543

Edited by the Institute of International Business, University of Gdańsk

\title{
Effects of regional market integration - a theoretical approach
}

The aim of this study is to review selected effects of regional market integration in theoretical terms. In contemporary conditions, when the processes of regional integration are increasingly challenged, this study will be a kind of return to the roots of regional economic integration. It covers a free trade area, a customs union, and a common market, for which selected effects of economic integration are presented. The literature indicates various, but not always positive, effects of market integration. As a set of factors motivates decisions concerning engagement in integration processes, it is worth pointing out objective economic effects as the basis for rational political decisions. In order to achieve the aim of the study, a critical review of literature published since the mid- $20^{\text {th }}$ century and a descriptive method have been used.

Keywords: theory of economic integration, free trade area, customs union, common market

JEL classification: F15

\section{Efekty regionalnej integracji rynkowej - ujęcie teoretyczne}

Celem niniejszego opracowania jest przegląd wybranych efektów regionalnej integracji rynkowej w ujęciu teoretycznym. We współczesnych uwarunkowaniach, gdy procesy regionalnej integracji są w coraz większym stopniu kwestionowane, opracowanie to będzie swoistym powrotem do źródeł regionalnej integracji gospodarczej. Zakres przedmiotowy obejmuje strefę wolnego handlu, unię celną oraz wspólny rynek, dla których przedstawione zostały wybrane efekty integracji. Literatura wskazuje na występowanie wielu nie zawsze pozytywnych efektów. Pamiętając, iż decyzje integracyjne motywowane są wieloma czynnikami, warto jeszcze raz przypomnieć obiektywne efekty ekonomiczne jako bazę dla podejmowania racjonalnych decyzji politycznych. Do realizacji celu opracowania wykorzystano metodę krytycznego przeglądu literatury publikowanej od połowy XX w. oraz metodę opisową.

Słowa kluczowe: teoria integracji gospodarczej, strefa wolnego handlu, unia celna, wspólny rynek Klasyfikacja JEL: F15 


\section{Introduction}

Regional economic integration is a common process in the contemporary world economy. At the same time, it has been subject to criticism in the last few years. The withdrawal of the US from the Trans-Pacific Partnership or the UK's decision to leave the EU (Brexit) are examples of growing skepticism toward integration. Therefore, it is worth returning to the fundamental question: when will countries be willing to integrate? The simple answer is as follows: when the longterm benefits of integration will predominate over costs in the assessment of these countries. In fact, it is all about the effects of integration.

As countries integrate due to the simultaneous occurrence of a whole set of factors (political, economic, social, etc.), it is worth pointing out the effects of economic nature. Unlike others, economic effects are quantifiable. Thus, the indication of the theoretical effects of economic integration and their subsequent measurement give grounds for an objective assessment of the advantage of the benefits over the costs of integration, constituting the basis for making rational decisions.

The primary goal of the study is to review selected effects of regional market integration in theoretical terms ${ }^{1}$. The article will be a kind of return to the roots of regional economic integration. It covers a free trade area, a customs union, and a common market, for which the basic effects of economic integration will be presented. In order to achieve the aims of the study, a critical review of literature published since the mid-20 $0^{\text {th }}$ century and a descriptive method have been used.

\section{The concept of economic integration}

Although the idea of economic integration traces back to ancient times, the very notion was introduced to the literature only after World War II [Machlup, 1976, p. 63]. There are a number of definitions of the term "economic integration" [Jovanović, 2015, pp. 2-7]. One of the first was proposed by Tinbergen [1954, p. 95]. According to him, integration may be said to be the creation of the most desirable structure of international economy, removing artificial hindrances to the optimal operation and introducing deliberately all desirable elements of co-ordination or unification. For Röpke [1959, p. 225], international economic integration means a situation in which trade links between different national economies develop as mutually beneficial and freely as if they were part of one economy. Balassa [1961]

1 The study is the first theoretical part of a broader study on the economic effects of market integration. In the second part, an overview of the existing empirical studies will be presented. 
defines economic integration as abolishing discrimination in an integrating area. The author introduced forms representing different degrees of economic integration. The process usually begins with a less advanced free trade area (FTA), through a customs union (CU), a common market (CM), and then developes an economic union until complete economic integration is achieved. Pelkmans [1984, p. 3] stated that the process of economic integration means the elimination of economic frontiers between two or more economies. In turn, Robson [1998, p. 1] drew attention to the institutional aspects, because for him, international economic integration is an institutional combination of separate national economies into larger economic blocks or communities. However, before higher stages of economic integration with policy coordination or institutions are achieved, they are usually preceded by a liberalization of trade in goods, and then removal of obstacles to the flow of production factors. Thus, most integration schemes start with market integration [Molle, 2006, pp. 9-10].

\section{Effects of regional market integration}

From the world's welfare point of view, the best choice is a worldwide liberalization (first best solution) [Misala, 2005, p. 450]. However, history teaches that liberalization on such a large scale, if at all possible, is undoubtedly a challenge. As a consequence, countries in search for economic benefits choose the second best solution, i.e., liberalization of flows in a territorially limited area [Lipsey, Lancaster, 1956]. At the initial stage of the development of integration theory, it was argued that integration on a regional scale would benefit not only the participating countries but the whole world. Lipsey [1960, p. 497] presented the logic of this reasoning as follows: since free trade maximizes global prosperity, and in the customs union there is a reduction in tariffs, which is, after all, an action towards free trade, so the customs union, even if it does not maximize it, certainly increases global welfare. Viner [1950] demonstrated the weaknesses of this argumentation and proved that creation of a customs union may bring both benefits or losses.

Along with the development of the theory and practice of regional economic integration, an increasing number of differentiated effects of this process were observed. In this study, due to its limited volume, only selected economic effects of market integration have been presented. 
Table 1. Selected effects of regional market integration

\begin{tabular}{|l|l|l|l|}
\hline & \multicolumn{1}{|c|}{ Free trade area } & \multicolumn{1}{|c|}{ Customs union } & \multicolumn{1}{c|}{ Common market } \\
\hline trade creation & $\begin{array}{l}\text { trade creation } \\
\text { trade diversion } \\
\text { production effect } \\
\text { trade diversion } \\
\text { terms of trade } \\
\text { trade expansion } \\
\text { trade suppression } \\
\text { trade deflection } \\
\text { deflection of production } \\
\text { deflection of investment } \\
\text { costs reduction } \\
\text { division effect } \\
\text { wrong specialization } \\
\text { investment reversal } \\
\text { investment creation }\end{array}$ & $\begin{array}{l}\text { microeconomic effects } \\
\text { macroeconomic effects } \\
\text { allocation effect } \\
\text { accumulation effect } \\
\text { localization effect } \\
\text { income effect } \\
\text { investment creation } \\
\text { investment diversion }\end{array}$ \\
\hline
\end{tabular}

Source: Own elaboration.

\subsection{Free trade area}

In an FTA scheme, countries abolish customs and quantitative restrictions in internal trade while leaving the freedom to shape relations with third countries: member states have the option of autonomously setting tariffs on imports from the rest of the world and introducing the rules of origin [Robson, 1998, p. 28; El-Agraa, 1999, p. 84].

In the traditional theory of regional integration, two primary static effects are analysed: the trade creation effect and the trade diversion effect. Both effects take place in the free trade area and customs union, while the third effect (trade deflection) is characteristic only for the free trade area.

The trade creation effect means an increase in trade flows between partners of the grouping resulting from trade liberalization, i.e., the abolition of tariffs and other restrictions in internal trade. This additional trade creation results from the differences in the costs of production of the same products between member countries and the increase in turnover. Additionally, the reduction of production costs leads to the reallocation of partners' resources to more effective uses. This way, less efficient producers in the free trade area stop producing and, in return, a new flow of trade between members is created.

Meade [1955] and Lipsey [1957, pp. 40-46] have exposed two other aspects of the trade creation effect. The production effect consists in a partial reduction or elimination of domestic production of the goods whose production after the formation of the grouping is less effective than that of the partner. Thus, the group's 
economy as a whole records an increase in production efficiency, although for domestic producers this may mean a loss. In turn, the consumption effect consists in increasing the consumption of goods imported from a partner country at the expense of national goods that previously met demand. More expensive goods produced in one country are then replaced by cheaper goods produced in a partner country. It benefits the consumer because the consumption can be increased within his budget.

The second static effect of the FTA is the trade diversion. The same abolition of barriers within a grouping that creates an increase in internal trade may also cause a shift of imports from a more efficient (cheaper) producer from a third country to a less efficient (more expensive) producer from a member country. This takes place when external barriers (e.g., duties) protect the less efficient producer in the grouping. In a short period, the trade diversion effect means a loss of the prosperity of a member country in relation to the rest of the world [Wysokinska, 1995, p. 870]. The trade diversion effect also has two aspects: (1) an increase in the cost of goods that were previously imported from third countries (as a result of a supply shift from a third country to a partner country); (2) loss of consumer surplus resulting from substitution of a cheaper commodity from a third country with a more expensive commodity produced in a grouping [Robson, 1998, p. 19].

From the point of view of the benefits or losses resulting from the creation of a specific FTA, the total increase in economic prosperity takes place when there is an advantage of trade creation over trade diversion effect. In that case there is trade expansion; otherwise, trade suppression occurs [Argüello, 2000, p. 16; Czepurko, 1972, p. 98; Cai, 2010, p. 9].

In the case of an FTA, a specific trade deflection effect may occur. It results from differences in tariffs between members and importing goods from a third country through the country with the lowest tariffs. If the grouping does not undertake corrective measures, the FTA moves towards a customs union with customs harmonized at the level of the country with the lowest tariffs [El-Agraa, 1989, p. 177]. The deflection effect is, however, only theoretical, as members of the FTA usually undertake actions in the form of rules of origin, i.e., regulations to ensure that privileges in the form of lack of duties and other restrictions are applied only to goods originating from member countries [Bobowski, 2008, p. 77]. Therefore, there are quite extensive systems of controlling whether a given product meets the conditions for its preference. They require the maintenance of border controls between member states, which can be technically complex and expensive. In addition to trade deflection, FTA creation may result in a deflection of production and investment [Balassa, 1961, pp. 70-71]. The deflection of production and investment in the area takes place when raw materials are intensively used in the production of goods which can be imported relatively cheaply from third countries 
[El-Agraa, 1989, p. 177]. In this case, differences in the level of duties on raw materials may distort the comparative advantage at the level of intermediate goods, resulting in a poor allocation of resources.

There is no agreement among the researchers dealing with the effects of integration as to the number and types of economic effects of integration forms. Wysokińska [1995, pp. 870-871] in her study presents, for example, additional effects characteristic for free trade areas and customs unions: (1) the effect of trade expansion, when lower market prices in member states stimulate an additional increase in domestic demand for imported goods; (2) the effect of costs reduction, due to the expansion of production as a result of trade creation; (3) the division effect, where the benefits of trade liberalization are shared between consumers (benefit from price reduction) and enterprises (profit from the increase in the scale of production); (4) the effect of wrong specialization, sometimes occurring in countries with a relatively large market and ineffective industry before entering the FTA (CU).

Nowadays, the declared goals of FTAs include not only an increase of internal trade but also a more general goal of economic growth acceleration. The rate of economic growth depends on supply and demand factors. On the supply side, it is about: (1) rationalization of the use of production factors, changes in the structure of the economy and foreign trade; (2) achieving the effects of the scale of production and sales and accelerating technical progress as a result of activity on a broader market; (3) multiplier mechanisms positively affecting economic growth [Bożyk, Misala, 2003, p. 101]. On the demand side, the following are indicated: (1) an increase in import demand resulting in the acceleration of trade development between partners, which means an additional impulse for GDP growth; (2) acceleration of investment demand resulting from increased competition on the FTA market; (3) multiplier effects leading to better use of production factors, increase of national income and consumer demand.

The impact of changes in supply and demand on economic growth leads to the creation of further effects. If the result of trade liberalization within the FTA is a change in the intensity of production of a given good in both countries, then it must also mean changes in the scope of investment. It is reasonable to ask whether the total sum of investments (in and outside of the group) increases as a result of an FTA creation or not. If total investments do not increase, investments from non-member countries are transferred to member states, which can be called investment reversal. If, however, the total investment in the world increases, then investment creation can be observed [Machlup, 1979, p. 164].

\subsection{Customs union}

The most important features of the customs union are: (1) elimination of import duties and other barriers between member states; (2) introduction of a common 
external tariff, and (3) division of customs revenues in accordance to the adopted formula. The creation of a CU, just like an FTA, affects changes in relative prices of goods in the member countries' markets and transforms trade, production, and consumption, affecting the welfare of states, the grouping, and the world. According to theorists of economic integration, the benefits and costs of the customs union result in particular from the impact of its creation on: (a) allocation of resources and international specialization; (b) economies of scale; (c) terms of trade; (d) productivity of the factors of production; (e) the rate of economic growth; (f) economic stability; (g) distribution of income [Ładyka, 2001, p. 85; Robson, 1998, p. 17; Lipsey, 1960, p. 496].

The effects of trade creation and trade diversion in a CU are analogous to the effects in an FTA. Their comparison should allow for a cost-benefit analysis of the creation of a customs union. However, this task is not easy, as there are many possible cases. Even a CU in which the trade creation effect predominates may be detrimental to at least one member country, and a CU with a predominant diversion effect may be beneficial for at least one country. If benefits and costs are not well shared between member states, compensatory transfers will be needed so that no country suffers losses [Berglas, 1979, p. 328; Molle, 1995, p. 98; de Melo, Panagariya, Rodrik, 1995, p. 165].

The creation of a CU may result in a redistribution of real income between member states and third countries, thus affecting the welfare of the global economy [Ładyka, 2001, p. 69]. This is due to the terms of trade effect, which has two aspects. First, it means a change in the proportions of benefits shared between the participants of the CU (internal aspect) and second, if the grouping has a significant share in the global market, integration can lead to a change of terms of trade with the rest of the world. In the first case, the relatively most significant benefits will go to smaller countries, which at the same time are forced to adjust their production structure in accordance with the system of comparative advantage. In the second case, if the integration group can influence global supply prices (e.g., through its bargaining power), the resulting benefits due to improved terms of trade can be even higher than full worldwide liberalization [Molle, 1995, pp. 95-96].

The CU also causes dynamic effects, i.e., those that stimulate the economic growth of the member countries [Brada, Méndez, 1988, p. 163; Schiff, Winters, 1998, p. 179]. These effects are in nature similar to the dynamic effects in the FTA, but their intensity is higher [Bożyk, Misala, 2003, p. 122].

\subsection{Common market}

A common market is the highest form of market integration, where economic freedoms characteristic for domestic markets are extended to partners [Pelkmans, 1984, p. 154]. The minimum requirement of the common market is to remove legal 
restrictions on the free flow of production factors between member countries; moreover, integration of the factor of production markets requires the use of harmonizing measures aimed at regulating labour, capital, and entrepreneurship markets [Ładyka, 2001, pp. 120-121].

According to Wysokińska and Witkowska [1999, p. 145], the creation of a common market leads to macro- and microeconomic effects. In the first case, the purchasing power of the population is growing, which stimulates demand and economic growth. A decrease of costs and prices affects the improvement of export competitiveness, leading to GDP growth. The liberalization of the financial market leads to a reduction in bank transaction costs, which stimulates the investments of enterprises and thus increases GDP. Economic growth, in turn, improves public finances and creates jobs. From a microeconomic point of view, the main benefits stemming from a common market are related to the impact of more intense competition and the restructuring processes of enterprises. In such conditions, companies are forced to innovate and apply new technologies.

The introduction of a single market should lead to three effects: allocation, accumulation, and localization [Misala, 2001, pp. 370-375]. The first effect takes place in a short run, while the occurrence of the other two requires a longer time horizon. The abolition or harmonization of barriers in the labour or capital flows can trigger their allocation to the place with the highest rate of return. In a short period, integration causes the outflow of factors from the abundant country (and therefore cheaper and with lower marginal productivity) to the country where they are relatively rare (with higher marginal productivity) and where a higher rate of return can be obtained. In theory, in the case of a completely liberalized market, it is possible that the prices of the same production factor and its marginal productivity will be equalized. Creation of a CM causes an optimal allocation of production factors, which promotes the growth of welfare, thus causing the income effect [Bożyk, Misala, 2003, p. 136].

The evolution of the customs union to the common market triggers and accelerates the process of accumulation of production factors [Misala, 2001, p. 370]. Accumulation, occurring when integration processes increase the rate of return on investment in physical capital, human capital, and knowledge, contributes to economic growth [Baldwin, Venables, 1995, p. 1614]. In the CM, it is easier to accumulate labour resources. There are multidirectional migration movements, and the calculations related to wage and wealth differences are supplemented by those concerning the possibility of raising qualifications. The common market also offers an easier capital accumulation. Portfolio and production capital move to places where the marginal advantage of their use is high. Additional benefits are revealed when the foreign capital flows into the country of the common market, where the marginal efficiency of capital utilization is high. Integration is, therefore, a factor encouraging the inflow of capital and increasing the propensity to save. 
If it is assumed that allocation and accumulation effects on a given common market occur simultaneously, then as a result of their overlapping, additional location effects appear, which result from the spatial concentration of economic activity [Molle, 1995, p. 165]. This is a consequence of the degree of attractiveness of specific countries or regions, determined by, i.a., environmental characteristics, mobility of workforce with diversified qualifications, as well as mobility of capital.

The current theory regarding the regional integration and FDI is not universal. Attempts to develop the theory deal with the study of the relationship between integration and flows of foreign direct investment and between integration and internationalization of the enterprise [Wysokińska, Witkowska, 1999, p. 50]. In the analysis of regional economic integration and FDI relationship of critical significance is the statement that trade and FDI do not have to be only substitutable, as claimed by Mundell [1957, pp. 321-335], but are also complementary [Yannopoulos, 1990, p. 244]. Static and dynamic effects of integration trigger processes of production reorganization stimulated mainly by the intensification of competition and economies of scale. As a result, it affects the creation of new location determinants for the FDI within the integration area. According to Kindleberger [1966, p. 71], foreign direct investments caused by integration take the form of either investment creation or investment diversion. In his understanding, investment creation consists of the inflow of external FDI to the integration group as a reaction to the trade diversion effect. On the other hand, investment diversion from one member state to another is a strategic response of enterprises to the trade creation effect, growing economies of scale, and specialization that lead to a reorganization of production. Both investment effects can occur simultaneously.

\section{Conclusions}

The review of literature conducted in this study confirms the existence of numerous economic effects of regional market integration. Even the least advanced, although the most common in practice, integration form (FTA), has a number of, not always positive, effects. The trade deflection effect complements the classic effects of trade creation and diversion. The occurrence of the latter is limited by the introduction of rules of origin. In addition to the classic static effects of FTAs, dynamic effects influencing economic growth are increasingly being analysed. The FTA members expect not only an increase in trade but more and more often an acceleration of economic growth. The same is true for CUs, characterized by greater centralization of economic decisions (creation and management of a common external tariff). In the $\mathrm{CU}$, an important terms of trade effect occurs which can mean a redistribution of real income between member states and third countries. In the 
common market, not only trade barriers but also obstacles for international migration of production factors are eliminated. This should, in consequence, bring additional effects, and the static and dynamic benefits of creating a common market are to be a multiplied sum of the effects achieved in the customs union.

The selected theoretical effects of regional market integration presented above do not allow for their full assessment. A complementary study will provide an overview of empirical studies on the subject.

\section{References}

Argüello R., 2000, Economic Integration: An Overview of Basic Economic Theory and other Related Issues, Economia, vol. 3.

Balassa B., 1961, The Theory of Economic Integration, Greenwood Press.

Baldwin R.E., Venables A.J., 1995, Regional Economic Integration, [in:] Handbook of International Economics, eds. G.M. Grossman, K. Rogoff, North-Holland, Princeton.

Berglas E., 1979, Preferential Trading Theory: The $n$ Commodity Case, Journal of Political Economy, vol. 87 , no. 2 .

Bobowski S., 2008, Teoria integracji ekonomicznej, [in:] Regionalizacja globalizacji, eds. J. Rymarczyk, W. Michalczyk, B. Drelich-Skulska, Wydawnictwo Akademii Ekonomicznej im. Oskara Langego we Wrocławiu, Wrocław.

Bożyk P., Misala J., 2003, Integracja ekonomiczna, PWE, Warszawa.

Brada J. C., Méndez J.A., 1988, An Estimate of the Dynamic Effects of Economic Integration, The Review of Economics and Statistics, vol. 70, no. 1.

Cai K.G., 2010, The Politics of Economic Regionalism: Explaining Regional Economic Integration in East Asia, Macmillan, Basingstoke.

Czepurko A., 1972, Cło w handlu międzynarodowym, PWE, Warszawa.

El-Agraa A.M., 1989, International Trade, Palgrave Macmillan, New York.

El-Agraa A.M., 1999, Regional Integration: Experience, Theory and Measurement, Macmillan, London.

Jovanović M.N., 2015, Economics of International Integration, Edward Elgar, Cheltenham, Northampton.

Kindleberger C.P., 1966, European Integration and The International Corporation, Columbia Journal of World Business, vol. 1, no. 1.

Ładyka S., 2001, Z teorii integracji gospodarczej, Oficyna Wydawnicza SGH, Warszawa.

Lipsey R.G., 1960, The Theory of Customs Unions: A General Survey, The Economic Journal, vol. 70 , no. 279 .

Lipsey R.G., 1957, The Theory of Customs Unions: Trade Diversion and Welfare, Economica, vol. 24, no. 93.

Lipsey R.G., Lancaster K., 1956, The General Theory of Second Best, The Review of Economic Studies, vol. 24, no. 1 .

Machlup F., 1976, A History of Thought on Economic Integration, [in:] Economic Integration: Worldwide, Regional, Sectoral, ed. F. Machlup, The Macmillan Press Ltd., London.

Machlup F., 1979, Integracja gospodarcza. Narodziny i rozwój idei, PWN, Warszawa.

Meade J.E., 1955, The Theory of Customs Union, North-Holland Pub. Co., Amsterdam. 
Melo J. de, Panagariya A., Rodrik D., 1995, The New Regionalism: A Country Perspective, [in:] New Dimensions in Regional Integration, eds. J. de Melo, A. Panagariya, Cambridge University Press, Cambridge.

Misala J., 2001, Wspótczesne teorie wymiany międzynarodowej i zagranicznej polityki ekonomicznej, Szkoła Główna Handlowa, Warszawa.

Misala J., 2005, Wymiana międzynarodowa i gospodarka światowa. Teoria i mechanizmy funkcjonowania, Oficyna Wydawnicza SGH, Warszawa.

Molle W., 1995, Ekonomika integracji europejskiej. Teoria, praktyka, polityka, Fundacja Gospodarcza NSZZ „Solidarność", Gdańsk.

Molle W., 2006, The Economics of European Integration: Theory, Practice, Policy, Ashgate, Aldershot.

Mundell R.A., 1957, International Trade and Factor Mobility, The American Economic Review, vol. 47 , no. 3 .

Pelkmans J., 1984, Market Integration in the European Community, Martinus Nijhoff Publishers, Hague.

Robson P., 1998, The Economics of International Integration, Routledge, London-New York.

Röpke W., 1959, International Order and Economic Integration, D. Reidel Publishing Company, Dordrecht.

Schiff M.W., Winters L.A., 1998, Dynamics and Politics in Regional Integration Arrangements: An Introduction, The World Bank Economic Review, vol. 12, no. 2.

Tinbergen J., 1954, International Economic Integration, Elsevier, Brussels.

Viner J., 1950, The Customs Union Issue, Carnegie Endowment for International Peace, New York.

Wysokińska Z., 1995, Międzynarodowa integracja regionalna-aspekty teoretyczne i empiryczne, Ekonomista, vol. 5-6.

Wysokińska Z., Witkowska J., 1999, Integracja europejska. Rozwój rynków, Wydawnictwo Naukowe PWN, Warszawa.

Yannopoulos G.N., 1990, Foreign Direct Investment and European Integration: The Evidence from the Formative Years of the European Community, Journal of Common Market Studies, vol. 28 , no. 3 .

P. Pasierbiak (『) pawel.pasierbiak@umcs.lublin.pl

Uniwersytet Marii Curie-Skłodowskiej, M. Curie-Skłodowska Sq. 5, 20-031 Lublin, Polska 